\title{
Thermal Characteristics Analysis on Multi- Heat Pipe Induced Heat Exchanger
}

\author{
P. Ram Kumar, M.Sivasubramanian, P.RajeshKanna, P.Raveendiran
}

\begin{abstract}
In this investigation of multi heat pipe induced in heat exchanger shows the developments in heat transfer is to improve the efficiency of heat exchangers. Water is used as a heat transfer fluid and acetone is used as a working fluid. Rotameter is set to measure the flow rate of cold water and hot water. To maintain the parameter as experimental setup. Then set the mass flow rate of hot water as $40 \mathrm{LPH}, 60 \mathrm{LPH}, 80 \mathrm{LPH}, 100 \mathrm{LPH}, 120 \mathrm{LPH}$ and mass flow rate of cold water as $20 \mathrm{LPH}, 30 \mathrm{LPH}, 40 \mathrm{LPH}, 50 \mathrm{LPH}$, and $60 \mathrm{LPH}$. Then $40{ }^{\circ} \mathrm{C}, 45^{\circ} \mathrm{C}, 50{ }^{\circ} \mathrm{C}, 55{ }^{\circ} \mathrm{C}, 60^{\circ} \mathrm{C}$ are the temperatures of hot water at inlet are maintained. To find some various physical parameters of $Q_{c}, h_{c}, R_{e}, \varepsilon, P_{n}, R_{t h}$. The maximum effectiveness of the investigation obtained from condition of Thi $60{ }^{\circ} \mathrm{C}$, Tci $32{ }^{\circ} \mathrm{C}$ and $100 \mathrm{LPH}$ mhi, $60 \mathrm{LPH}$ mci the maximum effectiveness attained as $57.25 \%$. Then the $m_{h i}$ as $100 \mathrm{LPH}, m_{c i}$ as $60 \mathrm{LPH}$ and $\mathrm{T}_{h i}$ at $40{ }^{\circ} \mathrm{C}$ as 37.6\%. It shows the effectiveness get increased about $34.3 \%$ to the maximum conditions.
\end{abstract}

Keywords : Multi Heat pipe, Heat exchanger, Mass flow rates, Temperature of hot water, Heat transfer rate, Effectiveness.

\section{INTRODUCTION}

$\mathrm{N}$ one has constrained space and the need of high warmth motion. Han Xiaoxing et al.[1] A novel concentric tube heat pipe exchanger to be utlized in waste heat recovery equipment with higher heat transfer efficiency at low temperature heat source with acetone as working fluid. Wermer et al. [2] Investigate scientific model manufacturing and a counter heat pipe with one of a kind heater and supply route frame work. The outcome demonstrate that heat pipe structure in equipped for taking action in a counter gravity start up is conceivable. Saud Ghani et al. [3] Investigate the execution of two fold pipe heat exchanger for air condition application with R-22 as refrigerant and came about the control utilization by blower is less with higher framework cooperative of execution. Shuangfeng Wang et al. [4] a test examination is directed to investigate the warmth transport ability of throbbing funnels (PHP) working with practical hot liquid by contracting them and un-adulterated water. The outcome demonstrate the heat

Revised Manuscript Received on December 30, 2019.

* Correspondence Author

P. RamKumar *, Department of Mechanical Engineering, Kalasalingam Academy of Research and Education, Krishnankoil, Virudhunagar, 626126, Tamil Nadu, India. Email: rkmailmech@ gmail.com

M.Sivasubramanian, Department of Automobile Engineering, Kalasalingam Academy of Research and Education, Krishnankoil, Virudhunagar, 626126, Tamil Nadu, India. Email: m.sivasubramanian@klu.ac.in

P.RajeshKanna, Department of Mechanical Engineering, Al Ghurair University, Dubai, United Arab Emirates. Email: prkanna@gmail.com

P.Raveendiran, Department of Mechanical Engineering, Alagappa Chettiar Government College of Engineering and Technology, Alagappa University, Karaikudi - 630003, Tamil Nadu, India. Email: praveendiran@gmail.com transport ability of PHP can be improved by utilizing FS-39E liquid under explicit conditions. Geun Jae et al. [5] the present study investigated that warmth temperature. Xiahou Guowei et al. [6] a vertical radiator with multi heart beat build up closes and a plane vanishing end for vertical CPU cooling is created. Anandh Takawale et al. [7] This paper reports the result of an experimental study to investigate the performance comparison between two pulsating heat pipes namely, a flat plate pulsating heat pipe (FPPHP) and a capillary tube pulsating heat pipe (CTPHP). Tong Miin et al. [8] in this thermal performance of a radically rotating pulsating heat pipe (RPHP) formulate by the interconnected $1 * 6 \mathrm{~mm}$ channel in the slim cushion were investigated.

V.Kiseev et al. [10] This study focuses on two phase stage warm control frame work namely loop thermosyphons (LTS) filled with nanofluids and their use as LED cooling device . Abhinav malhotra et al. [11] Semi-conductor nano tubes present an exciting avenue to create very thin one dimensional nano structure using available technique. Due to the large surface to volume ratio, nanotubes allows for an effective control over thermal energy transfer. Ye Bai et al. [12] determine the heat transfer performance and mechanism of separate heat pipe under various condition. S.A. Lurie et al. [13] in the present investigation of topology improvement approach is proposed to decide optical geometry of wick wintered inside a level warmth pipe. M.A.Chernysheva et al. [15] the paper present a model of heat and mass transfer in a cylindrical evaporator of a loop heat pipe(LPH) with allowance for the peculiarities of heat exchange in the evaporation zone formed by vapor removal grooves. E.N.Pis mennyi et al. [16] the paper manages the consequence of test investigations of warmth exchange perception of transport process in dissipated zone of $\mathrm{Al}$ heat pipe.

In that certain parameters are considered for the investigations such as heat carrying fluid, working fluid, geometrical parameter of heat exchanger and heat pipes. In this experimental work the experimental setup is fabricated by inserting the multi heat pipe induced heat exchanger, acetone is used as working fluid for this experiment, heat carrying fluid is water. The hot water mass flow rate is $40 \mathrm{LPH}$, $60 \mathrm{LPH}, 80 \mathrm{LPH}, 100 \mathrm{LPH}, 120 \mathrm{LPH}$ and mass flow rate of cold water is $20 \mathrm{LPH}, 30 \mathrm{LPH}, 40 \mathrm{LPH}, 50 \mathrm{LPH}, 60 \mathrm{LPH}$. Then maintain $40{ }^{\circ} \mathrm{C}, 45^{\circ} \mathrm{C}, 50{ }^{\circ} \mathrm{C}, 55^{\circ} \mathrm{C}, 60{ }^{\circ} \mathrm{C}$ for the temperatures of hot water at inlet. The experiment is carried out and heat transfer is examined with the heat transfer coefficient, heat transfer rate and effectiveness of the system. In this experimentation multi heat pipes are used to get maximum efficiency. 


\section{EXPERIMENTAl SET UP AND PROCEDURE}

\section{A. Experimental set up}

Multi heat pipe induced in heat exchanger is fabricated using the material which is given in Table 1 . The experimental setup is fabricated by the following parameters which given in Table 2. Water is used as a heat transfer fluids and acetone $\left(\mathrm{C}_{3} \mathrm{H}_{6} \mathrm{O}\right)$ is used as a working fluid for the experiment. Cold water is set as a condenser section and hot water set as an evaporator section. The heat pipe is filled with the acetone for the experiment.

\section{Table 1. Material used in the experimental setup}

\begin{tabular}{|l|c|}
\hline Properties & Materials \\
\hline Heat pipe material & $\mathrm{Cu}$ \\
\hline Shell material & GI \\
\hline Condenser material & GI \\
\hline Working fluid & Acetone \\
\hline Wick material & SS \\
\hline
\end{tabular}

Table 2. Geometrical parameters of experimental setup

\begin{tabular}{|l|c|}
\hline Properties & Dimensions \\
\hline $\begin{array}{l}\text { Total multi heat pipe } \\
\text { length }\end{array}$ & $1000 \mathrm{~mm}$ \\
\hline $\begin{array}{l}\text { Length of multi heat } \\
\text { pipe evaporator }\end{array}$ & $700 \mathrm{~mm}$ \\
\hline $\begin{array}{l}\text { Length of multi heat } \\
\text { pipe condenser }\end{array}$ & $200 \mathrm{~mm}$ \\
\hline $\begin{array}{l}\text { Length of adiabatic } \\
\text { heat pipe }\end{array}$ & $100 \mathrm{~mm}$ \\
\hline $\begin{array}{l}\text { Heat pipe inner } \\
\text { Diameter }\end{array}$ & $20 \mathrm{~mm}$ \\
\hline $\begin{array}{l}\text { Heat pipe outer } \\
\text { Diameter }\end{array}$ & $35 \mathrm{~mm}$ \\
\hline Shell Diameter & 03 \\
\hline Number of heat pipes & \\
\hline
\end{tabular}

Table 3. Thermo-physical properties of Acetone

\begin{tabular}{|l|c|}
\hline Properties & Acetone \\
\hline Boiling point & $56.08^{\circ} \mathrm{C}$ \\
\hline Melting point & $-94.9^{\circ} \mathrm{C}$ \\
\hline $\begin{array}{l}\text { Latent heat of } \\
\text { evaporation }(\lambda)\end{array}$ & $534 \mathrm{~kJ} / \mathrm{kg}$ \\
\hline Density of liquid $\left(\rho_{l}\right)$ & $784.5 \mathrm{~kg} / \mathrm{m}^{3}$ \\
\hline
\end{tabular}

As shown in Table 1 the given parameters are set for experimental work. Water is a heat transfer fluid and acetone is used as a working fluid. Then some material are used for experimental setup like GI pipe, and $\mathrm{Cu}$. The cold water is set as a condenser section and hot water set as an evaporator section. To maintain some parameter for experimental setup. Then set the mass flow rate flow of hot water as $40 \mathrm{LPH}$, 60LPH, $80 \mathrm{LPH}, 100 \mathrm{LPH}, 120 \mathrm{LPH}$ and mass flow rate of cold water as $20 \mathrm{LPH}, 30 \mathrm{LPH}, 40 \mathrm{LPH}, 50 \mathrm{LPH}, 60 \mathrm{LPH}$. The $40{ }^{\circ} \mathrm{C}, 45^{\circ} \mathrm{C}, 50{ }^{\circ} \mathrm{C}, 55^{\circ} \mathrm{C}, 60^{\circ} \mathrm{C}$ are the temperatures of hot water at inlet are maintained.

\section{RESULTS AND DISCUSSION}

In these parameters are considered for the investigation such as mass flow rates of cold and hot water, cold water temperature and hot water temperature are considered for study.

Heat transfer rate of cold water $\left(\mathrm{Q}_{\mathrm{c}}\right)$

$Q_{c}=m_{c} C_{p h}\left(T_{c o}-T_{c i}\right)$

Heat transfer rate to hot water $\left(\mathrm{Q}_{\mathrm{h}}\right)$

$Q_{h}=m_{h} C_{p h}\left(T_{h i}-T_{h o}\right)$

Area of condenser section (A)

$A=\Pi D L$

Effectiveness for cold Fluid $(\in)$

$\in=\frac{T_{\text {cout }}-T_{\text {cin }}}{T_{h \text { in }}-T_{\text {c in }}}$

Heat transfer coefficient (h)

$h=\frac{Q}{A *(\Delta T)_{l m}}$

Log mean temperature difference $\left((\Delta T)_{l m}\right)$

$(\Delta T)_{l m}=\frac{\left(T_{h i}-T_{c i}\right)-\left(T_{h o}-T_{c o}\right)}{\ln \frac{\left(T_{h i}-T_{c i}\right)}{\left(T_{h o}-T_{c o}\right)}}$

Reynolds number (Re)

$\mathrm{Re}=\frac{4 \dot{m}_{c}}{\pi D_{c} \mu}$ 
Nusselt number $(\mathrm{Nu})$

$\mathrm{Nu}=1.67\left\{\frac{R \varepsilon * P r}{x / D}\right\}^{0.333}$

Friction factor (f)

$\mathrm{f}=\frac{64}{\operatorname{Re}}(\operatorname{Re}<2300)$

Thermal Resistance $\left(\mathrm{R}_{\mathrm{th}}\right)$

$R_{t h}=\frac{T_{w}-T_{b}}{Q_{c}}$

$T_{b}=\frac{T_{c o}+T_{c i}}{2}, T_{w}=\frac{\Sigma T_{s}}{3}$

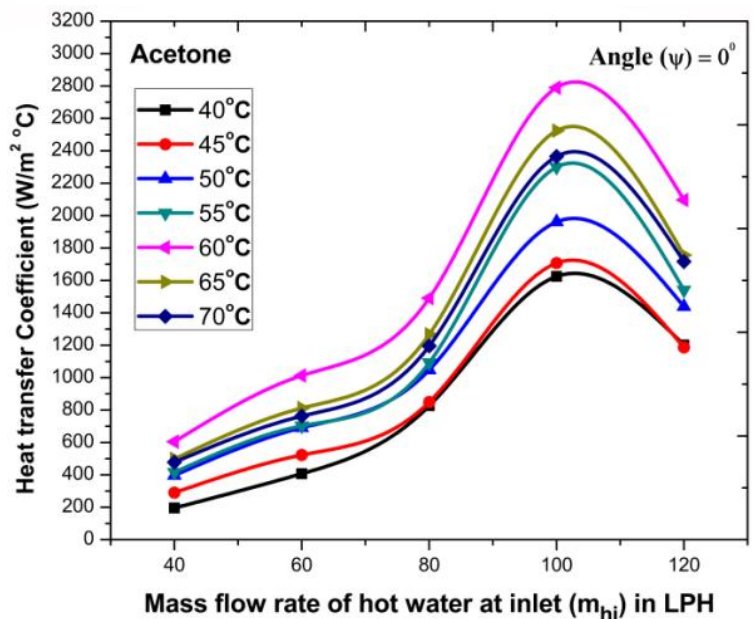

Fig 2. Mass flow rate of hot water at inlet vs Heat transfer coefficient

The graph is made with $h_{c} v s m_{h i}$ is shown in figure 2 . The $h_{c}$ is attained at maximum $\mathrm{T}_{\mathrm{hi}}$ and $\mathrm{m}_{\mathrm{hi}}$. $\mathrm{T}_{\mathrm{hi}}$ at $60^{\circ} \mathrm{C}, \mathrm{T}_{\mathrm{ci}}$ of $32^{\circ} \mathrm{C}$ and $100 \mathrm{LPH} \mathrm{m}_{\mathrm{hi}}, 60 \mathrm{LPH} \mathrm{m}_{\mathrm{ci}}$ the $\mathrm{h}_{\mathrm{c}}$ attained as $2790.02 \mathrm{~W} / \mathrm{m}^{2}{ }^{\circ} \mathrm{C}$, at same above condition for $120 \mathrm{LPH}$ it reduced to 2097.23 $\mathrm{W} / \mathrm{m}^{2}{ }^{\circ} \mathrm{C}$. At $40{ }^{\circ} \mathrm{C} \mathrm{T}_{\mathrm{hi}}, 32{ }^{\circ} \mathrm{C} \mathrm{T}_{\mathrm{ci}}$ and $100 \mathrm{LPH}$ of $\mathrm{m}_{\mathrm{hi}}, 60 \mathrm{LPH}$ $\mathrm{m}_{\mathrm{ci}}$ the minimum $\mathrm{h}$ attained as $1625.01 \mathrm{~W} / \mathrm{m}^{2}{ }^{\circ} \mathrm{C}$, at same above condition for $120 \mathrm{LPH}$ it reduced to $1202.42 \mathrm{~W} / \mathrm{m}^{2}{ }^{\circ} \mathrm{C}$ From the above calculations it is observed that the $h_{c}$ attained is maximum when $\mathrm{T}_{\mathrm{hi}}$ and $\mathrm{m}_{\mathrm{hi}}$ are maximum.

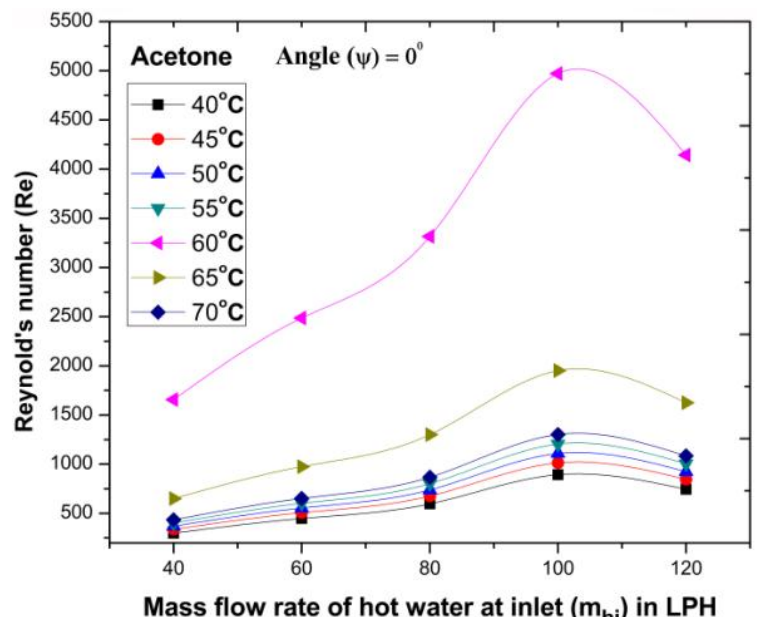

Fig 3. Mass flow rate of hot water at inlet vs Reynolds number

The graph in Figure 3. Shows the $\mathrm{R}_{\mathrm{e}} \mathrm{vs} \mathrm{m}_{\mathrm{hi}}$. The variation in Reynolds number is observed in graph. $\mathrm{T}_{\mathrm{hi}}$ at $60{ }^{\circ} \mathrm{C}, \mathrm{T}_{\mathrm{ci}}$ of 32

${ }^{\circ} \mathrm{C}$ and $100 \mathrm{LPH} \mathrm{m} \mathrm{hi}_{\mathrm{hi}}, 60 \mathrm{LPH} \mathrm{m}_{\mathrm{ci}}$ the $\mathrm{R}_{\mathrm{e}}$ attained as 4972 . At
$40{ }^{\circ} \mathrm{C} \mathrm{T}_{\mathrm{hi}}, 32{ }^{\circ} \mathrm{C} \mathrm{T}_{\mathrm{ci}}$ and $100 \mathrm{LPH}$ of $\mathrm{m}_{\mathrm{hi}}, 60 \mathrm{LPH} \mathrm{m}_{\mathrm{ci}}$ the minimum $R_{e}$ attained as 893.39. In the both conditions at 120 LPH Re gets reduced. From the above basis the $R_{e}$ get increased when $\mathrm{T}_{\mathrm{hi}}$ and $\mathrm{m}_{\mathrm{hi}}$ increased.

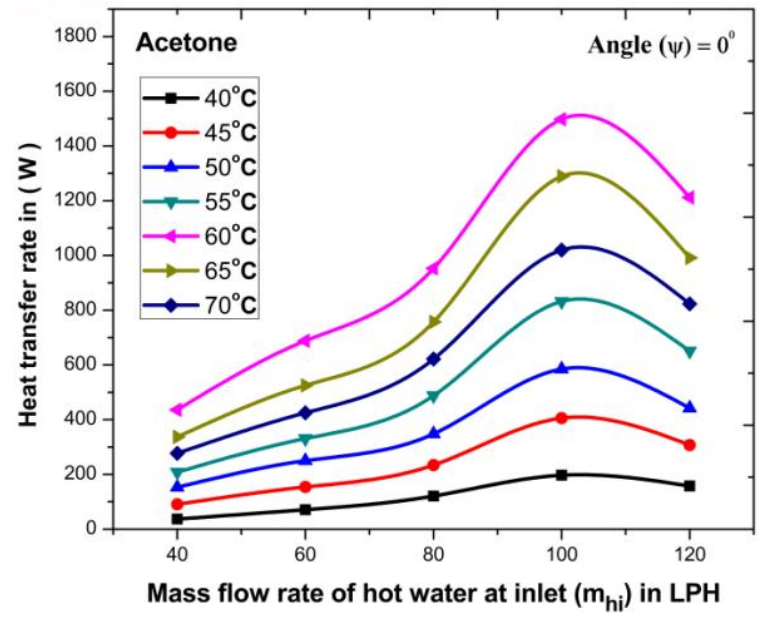

Fig 4. Mass flow rate of hot water at inlet vs Heat transfer rate

The plots graph is made with $\mathrm{Q}_{\mathrm{c}}$ vs $\mathrm{m}_{\mathrm{hi}}$ is shown in figure 4 . The enhancement in $\mathrm{Q}_{\mathrm{c}}$ is attained at maximum of $\mathrm{T}_{\mathrm{hi}}$ and $\mathrm{m}_{\mathrm{hi}}$. The $\mathrm{T}_{\mathrm{hi}}$ at $60^{\circ} \mathrm{C}, \mathrm{T}_{\mathrm{ci}}$ of $32^{\circ} \mathrm{C}$ and $100 \mathrm{LPH} \mathrm{m}$ hi, $60 \mathrm{LPH} \mathrm{m}_{\mathrm{ci}}$ the maximum $\mathrm{Q}_{\mathrm{c}}$ attained as $1498.32 \mathrm{~W}$. At $\mathrm{T}_{\mathrm{hi}} 40^{\circ} \mathrm{C}, \mathrm{T}_{\mathrm{ci}} 32^{\circ} \mathrm{C}$ and $100 \mathrm{LPH} \mathrm{m}_{\mathrm{hi}}, 60 \mathrm{LPH} \mathrm{m}_{\mathrm{ci}}$ the minimum $\mathrm{Q}_{\mathrm{c}}$ attained as 197.24 W. In $120 \mathrm{LPH}$ it gets reduced. The maximum $\mathrm{Q}_{\mathrm{c}}$ attained is due to maximum $\mathrm{T}_{\mathrm{hi}}$ and maximum $\mathrm{m}_{\mathrm{hi}}$. From this it observed that as $T_{h i}$ and $m_{h i}$ increases, $Q_{c}$ is increased for the given condition.

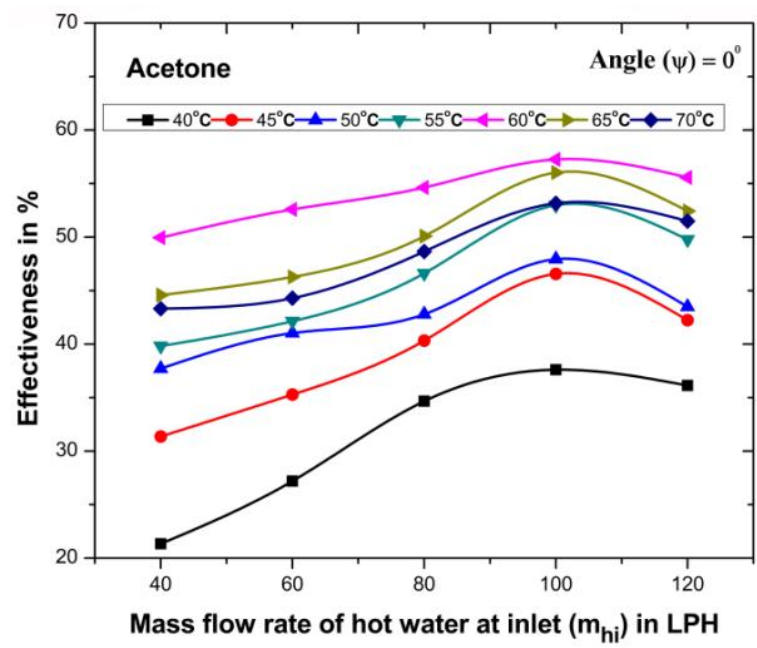

Fig 5. Mass flow rate of hot water at inlet vs Effectiveness

The graph in figure 5 shows the $\in \mathrm{vs} \mathrm{m}_{\mathrm{hi}}$. The improvement in $\in$ is attained at maximum $\mathrm{T}_{\mathrm{hi}}$. At $\mathrm{T}_{\mathrm{hi}} 60{ }^{\circ} \mathrm{C}, \mathrm{T}_{\mathrm{ci}} 32^{\circ} \mathrm{C}$ and 100 $\mathrm{LPH} \mathrm{m}_{\mathrm{hi}}, 60 \mathrm{LPH}_{\mathrm{ci}}$ the maximum $\in$ attained as $57.25 \%$ at $120 \mathrm{LPH}$ it was $55.57 \%$. The value of $\in$ attained at $40{ }^{\circ} \mathrm{C} \mathrm{T}_{\mathrm{hi}}$, $32{ }^{\circ} \mathrm{C} \mathrm{T}_{\mathrm{ci}}$ and $100 \mathrm{LPH} \mathrm{m}$ hi, $60 \mathrm{LPH} \mathrm{m}_{\mathrm{ci}}$ as $37.6 \%$ at $120 \mathrm{LPH}$ it was $36.13 \%$. In the both the conditions $120 \mathrm{LPH}$ it reduced. The Effectiveness get increased when the $T_{h i}$ and $m_{h i}$ get increased. 


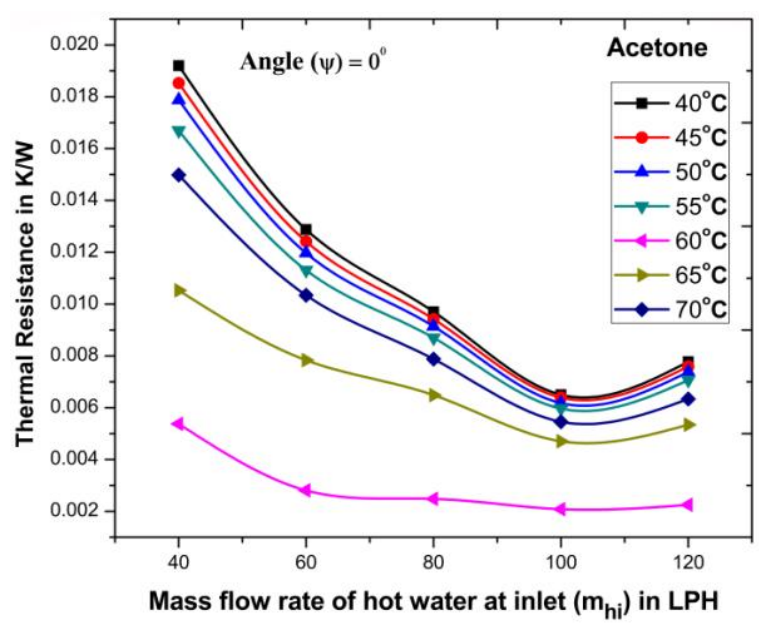

Fig 6. Mass flow rate of hot water at inlet vs Thermal resistance

The graph in Figure 6. Shows that $\mathrm{R}_{\mathrm{th}} \mathrm{vs} \mathrm{m}_{\mathrm{hi}}$ The Variation in Thermal resistance is attained at $\mathrm{T}_{\mathrm{hi}}$ as $60{ }^{\circ} \mathrm{C}, \mathrm{T}_{\mathrm{ci}} 32^{\circ} \mathrm{C}$ and $100 \mathrm{LPH} \mathrm{m}$ hi $60 \mathrm{LPH} \mathrm{m}_{\mathrm{ci}}$ the minimum $\mathrm{R}_{\mathrm{th}}$ attained as 0.00208 . The value of $\mathrm{R}_{\mathrm{th}}$ attained at $40^{\circ} \mathrm{C} \mathrm{T}_{\mathrm{hi}}, 32{ }^{\circ} \mathrm{C} \mathrm{T}_{\mathrm{ci}}$ and $100 \mathrm{LPH} \mathrm{m}_{\mathrm{hi}}, 60 \mathrm{LPH} \mathrm{m}_{\mathrm{ci}}$ as 0.00652 . At $120 \mathrm{LPH}$ the $\mathrm{R}_{\mathrm{th}}$ gets increased. This shows that there is decreases in $R_{t h}$ is observed while increasing the mass flow rate and temperature at inlet condition.

\section{CONCLUSION}

In this work heat pipe heat exchanger is fabricated and analysed with various mass flow rate $\left(\mathrm{m}_{\mathrm{hi}}\right)$ and temperature inlet for both cold and hot water. The observation reveals that when mass flow rate for hot water increases the performance of the system also increases. When the $\left(\mathrm{m}_{\mathrm{hi}}\right)$ increases to $\mathrm{m}_{\mathrm{hi}}$ as $100 \mathrm{LPH}, \mathrm{m}_{\mathrm{ci}}$ as $60 \mathrm{LPH}, \mathrm{T}_{\mathrm{hi}}$ at $60{ }^{\circ} \mathrm{C}$ and $\mathrm{T}_{\mathrm{ci}}$ as $32^{\circ} \mathrm{C}$ the maximum heat transfer performace is achieved this is the optimum observed condition.

- Maximum heat transfer rate is attained from the condition the $\mathrm{T}_{\mathrm{hi}}$ at $60^{\circ} \mathrm{C}, \mathrm{T}_{\mathrm{ci}}$ of $32^{\circ} \mathrm{C}$ and $100 \mathrm{LPH}$ $\mathrm{m}_{\mathrm{hi}}, 60 \mathrm{LPH} \mathrm{m}_{\mathrm{ci}}$ the maximum $\mathrm{Q}_{\mathrm{c}}$ attained as $1498 \mathrm{~W}$, which is $86.83 \%$ higher than the heat transfer rate obtained for $\mathrm{m}_{\mathrm{hi}}$ as $100 \mathrm{LPH}, \mathrm{m}_{\mathrm{ci}}$ as $60 \mathrm{LPH}$ and $\mathrm{T}_{\mathrm{hi}}$ at $40{ }^{\circ} \mathrm{C}$ as $197.24 \mathrm{~W}$. This shows that at optimum condition as $120 \mathrm{LPH}$ and $60{ }^{\circ} \mathrm{C}$ the maximum heat transfer rate is achieved.

- Highest effectiveness of the investigation obtained at condition $\mathrm{T}_{\mathrm{hi}} 60{ }^{\circ} \mathrm{C}, \mathrm{T}_{\mathrm{ci}} 32{ }^{\circ} \mathrm{C}$ and $100 \mathrm{LPH} \mathrm{m}_{\mathrm{hi}}, 60$ $\mathrm{LPH} \mathrm{m}_{\mathrm{ci}}$ the maximum $\in$ attained as $57.25 \%$. Which is $34.32 \%$ greater than the effectiveness obtained for $37.6 \%$. Effectiveness of the investigation is obtained maximum at optimum stated condition.

- Maximum heat transfer coefficient is obtained from the condition $\mathrm{T}_{\mathrm{hi}} 60{ }^{\circ} \mathrm{C}, \mathrm{T}_{\mathrm{ci}} 32^{\circ} \mathrm{C}$ and $100 \mathrm{LPH} \mathrm{m}_{\mathrm{hi}}$, $60 \mathrm{LPH} \mathrm{m} \mathrm{m}_{\mathrm{ci}}$ is observed as $2790.02 \mathrm{~W} / \mathrm{m}^{2}{ }^{\circ} \mathrm{C}$ that is $41.75 \%$ higher than the heat transfer coefficient achieved for $\mathrm{m}_{\mathrm{hi}}$ as $100 \mathrm{LPH}, \mathrm{m}_{\mathrm{ci}}$ as $60 \mathrm{LPH}$ and $\mathrm{T}_{\mathrm{hi}}$ at $40{ }^{\circ} \mathrm{C}$ as $1625.01 \mathrm{~W} / \mathrm{m}^{2}{ }^{\circ} \mathrm{C}$.

- Thermal resistance of the system tends to decreases, this increases the performance of the heat pipe heat exchanger, for the same stated condition it was $68.09 \%$ decrease trends are observed.

- Reynolds number tends to increase while increasing $\mathrm{m}_{\mathrm{hi}}$ as $100 \mathrm{LPH}, \mathrm{m}_{\mathrm{ci}}$ as $60 \mathrm{LPH}$ and $\mathrm{T}_{\mathrm{hi}}$ at $40^{\circ} \mathrm{C}$ as

the mass flow rate of hot fluid and temperature at inlet condition, flow behaves laminar throughout the investigation there was $82.03 \%$ increase in values are observed for same above revealed condition.

\section{APPENDIX}

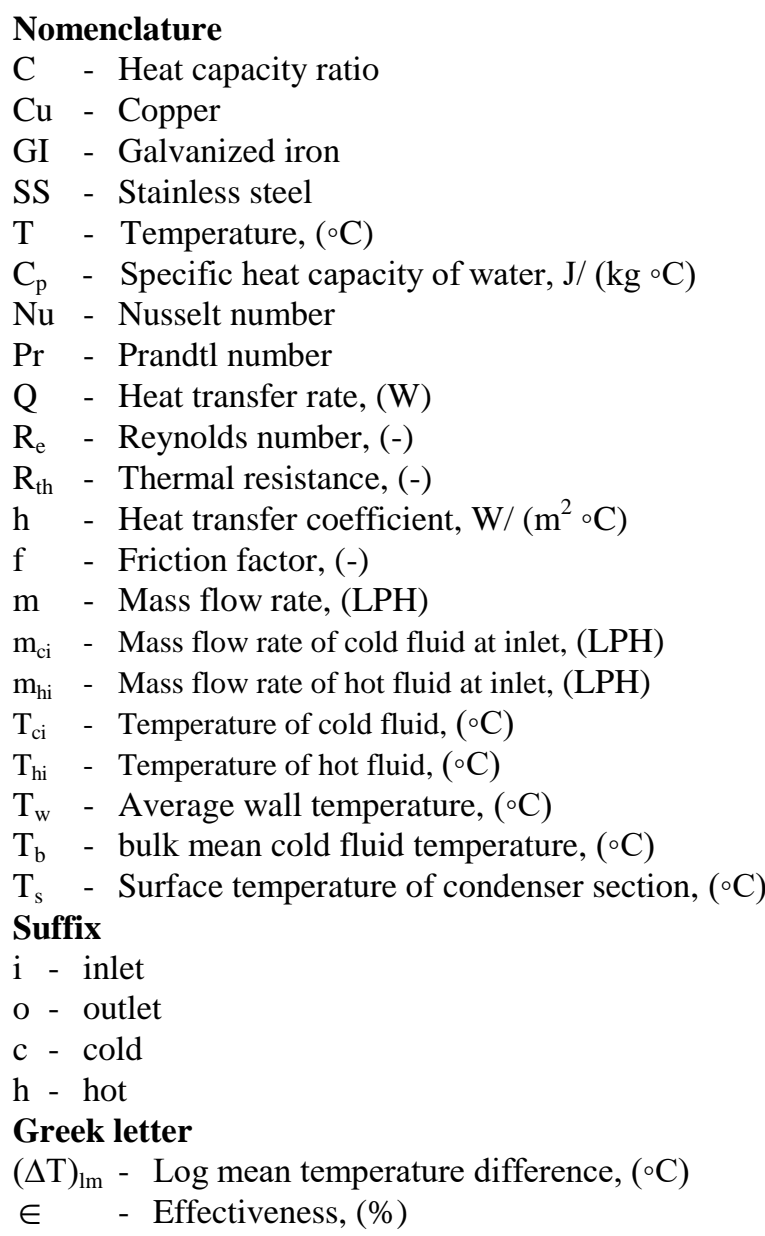

\section{REFERENCES}

1. Han Xiaoxing, Wang Yaxiong, "Experimental investigation of thermal performance of a novel concentric tube heat pipe heat exchanger," International journal of heat and mass transfer 2018, 127, pp. 1338-1342.

2. R.Wermer, Martin J.Ward,Justin D.Simpson,Robert A.Zimmerman, James A.Stewart,"Ahigh capacityself priming counter gravity heat pipe,” International journal of heat and mass transfer. 2018, 125, pp. 1369-1378.

3. Saud Ghani,S.Mahmoud, A.Gamaledin, "Experimental Investigation of double pipe heat exchanger in air conditioning application," International journal of heat pipe. 2018, 158, pp. 801-811.

4. Shuangfeng Wang, Zirong Lin, Weibao Zhang, Jinjian Chen, "Experimental study on pulsating heat pipe with functional thermal fluids," International journal of heat and mass transfer, 2009, 52, pp. 5276-5279.

5. Guen Jae Lee, Leonard D. Tijing, Bock Choon Pak, "Use of catalytic materials for the mitigation of mineral fouling," International communication in heat and mass transfer, 2006, 33, pp. 14-23.

6. Xiahou Guowei, Zhang Junjie, Ma Rui, Liu Yepang, "Novel heat pipe radiator for vertical CPU cooling and its experimental study," International journal of heat and mass transfer, 2019, 130, pp. 912-922.

7. Anand Takawale, Alex Sielaff, Peter Stephan, Aravind Pattamatta, "A comparative study of flow regimes and thermal performance between flat plate pulsating heat pipe and capillary tube pulsating heat pipe," Applied thermal engineering, 2018, pp. 11-19. 
8. Tong Miin Liou, Shyy Woei Chang, Wei Ling Cai, "Thermal fluid characteristics of pulsating in radially rotating thin pad", International journal of heat and mass transfer, 2019, 131, pp. 273-290.

9. V.Kiseev, O.Sazhin, "Heat transfer enhancement in a loop thermosyphon using nanoparticles/ water nanofluids," International journal of heat and mass transfer, 2019, 132, pp. 557-564.

10. Abhinav Malhotra, Martin Maldovan, "Thermal transport in semiconductor nanotubes," International journal of heat and mass transfer, 2019, 130, pp. 368-374.

11. Ye Bai, Liang Wang, Shuang Zhang, Ningning Xie, "Heat transfer characteristics of natural circulation separate heat pipe under various operating condition," International journal of heat and mass transfer, 2018,126, pp. 191-200.

12. S.A. Lurie, L.N. Rabiniskiy, Y.O. Solyaev, "Topology optimization of the wick geometry in a flat plate heat pipe," International journal of heat and mass transfer, 2019, 128, pp. 239-247.

13. Gyoko Nagayama, Takaharu Tsuruta, Shunya Gyotoku, "Thermal performance of flat micro heat pipe with converging microchannels," international journal of heat and mass transfer, 2018,122, pp. 375-382.

14. M.A.Chernysheva, Y.F.maydanik, "simulation of heat and mass transfer in a cylindrical evaporator of a loop heat pipe," international journal of heat and mass transfer, 2019, 131, pp. 442-449.

15. E.N. Pis mennyi, S.M. Khayrnasov, B.M. Rassamakin, "Heat transfer in evaporation zone of aluminium grooved heat pipes", International journal of Heat and Mass Transfer, 2018, 127, pp. 80-88.

\section{AUTHORS PROFILE}

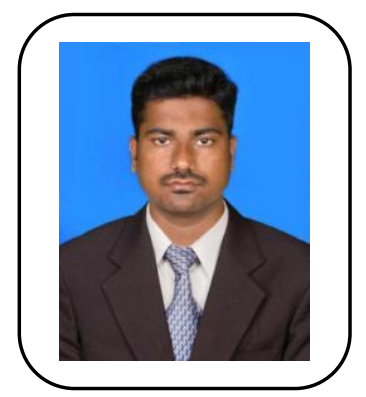

Mr. P.Ramkumar, Assistant Professor in Mechanical Engineering at Kalasalingam University. I have completed B.E (Mechanical Engineering), M.E (Thermal Power Engineering), pursuing Ph.D (Thermal Engineering) having five years of teaching experience for U.G and P.G students. I am life time member of Indian Society of Heat and Mass Transfer (ISHMT - IIT Madras). I have published two papers in International journal, three papers published in International conference and four papers in National conference. I am doing my research in the field of heat pipe and compact heat exchanger.

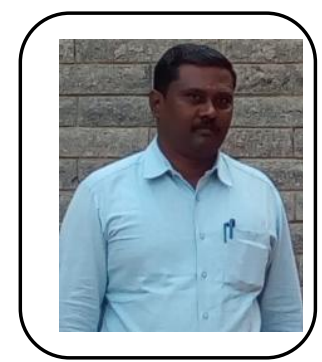

Dr. M. Sivasubramanian, Associate Professor in Automobile Engineering at Kalasalingam University. I have completed $\mathrm{Ph} . \mathrm{D}$ in thermal engineering, I am having twenty years of teaching experience. I am life time member of Indian Society of Heat and Mass Transfer (ISHMT - IIT Madras), MISTE, SAE. Seven papers in International journal and twenty five papers in International / National conference. Research area in the fluid flow.

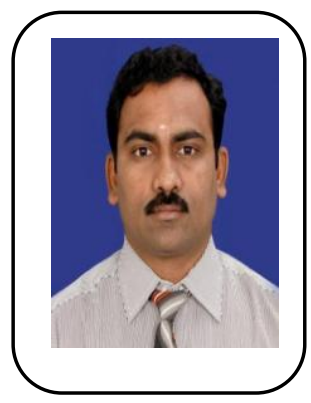

Dr. P. Rajesh Kanna, Professor in Mechanical Engineering at Al Ghurair University, Dubai, United Arab Emirates. I have completed in Ph.D in IIT - Guwahati. Post Doc at National Taiwan University of Science and Technology, Department of Mechanical Engineering, CFD, Taiwan, Taipei. Research expert in experimentation and numerical analysis in heat transfer, fluid mechanics, CFD. His h-index is 16 , i-10-index is 21, and Citation Statistics is 611.

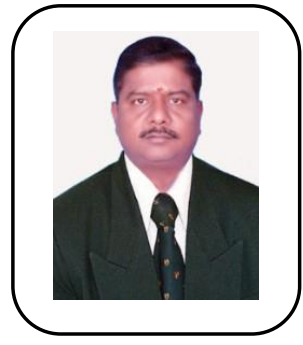

Dr. P. Raveendiran, Associate Professor at Alagappa Chettiar Government College of Engineering and Technology, Alagappa University, Karaikudi. Ph.D has been completed in Annamalai University. I have published Eight International journal, one national journal, and two national / international conferences. One book published in heat and mass transfer. I am having teaching experience of seventeen years. I am expertise in the field of Heat pipe, heat exchanger. 